\title{
Relative stability and significance of dawsonite and aluminum minerals in geologic carbon sequestration
}

\author{
John P. Kaszuba, ${ }^{1}$ Hari S. Viswanathan, ${ }^{2}$ and J. William Carey ${ }^{2}$ \\ Received 25 January 2011; revised 2 March 2011; accepted 8 March 2011; published 22 April 2011.
}

[1] Computer simulations predict dawsonite, $\mathrm{NaAlCO}_{3}(\mathrm{OH})_{2}$, will provide long-term mineral sequestration of anthropogenic $\mathrm{CO}_{2}$ whereas dawsonite rarely occurs in nature or in laboratory experiments that emulate a carbon repository. Resolving this discrepancy is important to determining the significance of dawsonite mineralization to the long-term security of geologic carbon sequestration. This study is an equilibrium-based experimental and modeling evaluation of underlying causes for inconsistencies between predicted and observed dawsonite stability. Using established hydrothermal methods, 0.05 molal $\mathrm{NaHCO}_{3}$ aqueous solution and synthetic dawsonite were reacted for 18.7 days $\left(449.2\right.$ hours) at $50^{\circ} \mathrm{C}, 20 \mathrm{MPa}$. Temperature was increased to $75^{\circ} \mathrm{C}$ and the experiment continued for an additional 12.3 days (295.1 hours). Incongruent dissolution yielded a dawsonite-gibbsite-nordstrandite assemblage. Geochemical simulations using Geochemist's Workbench and the resident database thermo.com.V8.R6 ${ }^{+}$ incorrectly predicted a dawsonite-diaspore assemblage and underestimated dissolved aluminum by roughly 100 times. Higher aqueous aluminum concentrations in the experiment suggest that dawsonite or diaspore is less stable than predicted. Simulations employing an alternate database, thermo.dat, correctly predict dawsonite and dawsonitegibbsite assemblages at 50 and $75^{\circ} \mathrm{C}$, respectively, although dissolved aluminum concentrations are still two to three times lower than experimentally measured values. Correctly reproducing dawsonite solubility in standard geochemical simulations requires an as yet undeveloped internally consistent thermodynamic database among dawsonite, gibbsite, boehmite, diaspore, aqueous aluminum complexes and other Al-phases such as albite and kaolinite. These discrepancies question the ability of performance assessment models to correctly predict dawsonite mineralization in a sequestration site. Citation: Kaszuba, J. P., H. S. Viswanathan, and J. W. Carey (2011), Relative stability and significance of dawsonite and aluminum minerals in geologic carbon sequestration, Geophys. Res. Lett., 38, L08404, doi:10.1029/ $2011 \mathrm{GL} 046845$.

\section{Introduction}

[2] Storage of anthropogenic $\mathrm{CO}_{2}$ in saline aquifers, depleted oil and gas reservoirs, and unmineable coal seams

\footnotetext{
${ }^{1}$ Department of Geology and Geophysics and School of Energy Resources, University of Wyoming, Laramie, Wyoming, USA.

${ }^{2}$ Earth and Environmental Sciences Division, Los Alamos National Laboratory, Los Alamos, New Mexico, USA.

Copyright 2011 by the American Geophysical Union. 0094-8276/11/2011GL046845
}

is one of several strategies targeting the problem of global climate change. The paradigm of $\mathrm{CO}_{2}$ storage revolves around an idealized progression wherein geochemical trapping mechanisms follow physical trapping [Benson and Cook, 2005]. Geochemical mechanisms for $\mathrm{CO}_{2}$ trapping (solubility, ionic, and mineral trapping) possess greater long-term stability than physical trapping mechanisms (structural, stratigraphic, capillary, and hydrodynamic trapping) because $\mathrm{CO}_{2}$ no longer exists as a separate mobile phase within the fluid-rock system. Of these trapping mechanisms, mineral trapping is considered the most secure mechanism for carbon storage in geologic systems because of the relative permanence of minerals. However, mineral trapping occurs at reaction rates on the scale of thousands of years or longer. These rates are the slowest of any of the trapping mechanisms, placing mineral trapping last in the progression. The ultimate fate of $\mathrm{CO}_{2}$ hinges on the significance of mineral trapping (thousands of years and longer), yet the science of $\mathrm{CO}_{2}$ sequestration cannot yet predict with any certainty which mineral traps will form.

[3] Dawsonite, $\mathrm{NaAlCO}_{3}(\mathrm{OH})_{2}$, is considered a promising phase for long-term mineral sequestration of $\mathrm{CO}_{2}$. It could form from common aluminosilicates (alkali feldspar, muscovite, and kaolinite) and Na-bearing brines that do not precipitate typical $\mathrm{Ca}_{-}, \mathrm{Mg}-$, and $\mathrm{Fe}$-bearing carbonate minerals, potentially increasing the total mass of carbonate minerals and consequently the storage capacity of a carbon repository. Although modeling studies predict dawsonite formation in carbon repositories [Johnson et al., 2001; Xu et al., 2004; Knauss et al., 2005; Zerai et al., 2006; Xu et al., 2007] and in enhanced oil recovery projects using $\mathrm{CO}_{2}$ [Cantucci et al., 2009], dawsonite rarely occurs in natural $\mathrm{CO}_{2}$ fields [Pearce et al., 1996; Klusman, 2003; Wilkinson et al., 2009] and does not appear in laboratory experiments emulating conditions in a carbon repository [Pearce et al., 1996; Kaszuba et al., 2003, 2005; Newell et al., 2008; Hangx and Spiers, 2009]. This discrepancy fuels debate regarding the importance of dawsonite to carbon capture and storage [Hellevang et al., 2005; Bénézeth et al., 2007; Wilkinson et al., 2009; Hellevang et al., 2010]. Resolving this discrepancy is important to determining the significance of dawsonite mineralization to the long-term security of geologic carbon sequestration. For example, mineralization calculations based on geochemical simulations are a crucial component of performance/risk assessment models that evaluate the long term fate of $\mathrm{CO}_{2}$ [Viswanathan et al., 2008].

[4] The purpose of this paper is to begin to evaluate the underlying causes for inconsistencies between predicted and observed dawsonite stability. We use the controlled conditions of a geochemical laboratory experiment to evaluate dawsonite stability and reactivity. We compare these 
Table 1. Water Chemistry as a Function of Time in Dawsonite-Fluid Experiment, 50 and $75^{\circ} \mathrm{C}, 20 \mathrm{MPa}$

\begin{tabular}{|c|c|c|c|c|c|c|c|c|}
\hline $\begin{array}{l}\text { Elapsed } \\
\text { Time (h) }\end{array}$ & $\begin{array}{c}\mathrm{P} \\
(\mathrm{MPa})\end{array}$ & $\mathrm{T}\left({ }^{\circ} \mathrm{C}\right)$ & $\begin{array}{c}\text { Total } \\
\mathrm{Al}^{\mathrm{a}}(\mathrm{uM})\end{array}$ & $\begin{array}{l}\text { Total } \\
\mathrm{Na}^{\mathrm{b}} \\
(\mathrm{mM})\end{array}$ & $\begin{array}{c}\text { Total } \mathrm{C}^{\mathrm{c}} \\
\left(\text { as } \mathrm{mM} \mathrm{CO} \mathrm{CO}_{2}\right)\end{array}$ & $\begin{array}{c}\text { Bench } \\
\mathrm{pH}^{\mathrm{d}}\end{array}$ & $\begin{array}{c}\text { In-Situ } \\
\mathrm{pH}^{\mathrm{e}}\end{array}$ & Comment \\
\hline - & 0.1 & 25 & 0 & 50 & 50 & - & - & solution as synthesized ${ }^{\mathrm{f}}$ \\
\hline 0.0 & 0.1 & 25 & 0.185 & 51 & 47.7 & 8.89 & - & analysis of starting solution \\
\hline 257.8 & 19.6 & 50 & 27.80 & 51 & 49.9 & 8.54 & 8.42 & \\
\hline 348.7 & 20.2 & 50 & 28.24 & 51 & 49.0 & 8.54 & 8.42 & \\
\hline 449.2 & 19.8 & 50 & 19.52 & 51 & 49.7 & 8.56 & 8.44 & \\
\hline 55.9 & 19.2 & 75 & 88.51 & 51 & 50.6 & 8.57 & 8.41 & \\
\hline 149.7 & 20.2 & 75 & 62.98 & 52 & 53.2 & 8.55 & 8.39 & \\
\hline 295.1 & 20.2 & 75 & 59.30 & 50 & $\mathrm{NA}^{\mathrm{g}}$ & NA & NA & filtered with $0.45 \mu \mathrm{m}$ filter \\
\hline 295.1 & 20.2 & 75 & 63.94 & 52 & NA & 8.48 & 8.33 & \\
\hline 297.3 & 0.1 & 24 & 56.52 & 49 & NA & NA & NA & quench sample, filtered with $0.45 \mu \mathrm{m}$ filter \\
\hline 297.3 & 0.1 & 24 & 99.30 & 50 & NA & 8.58 & - & quench sample, unfiltered \\
\hline 297.3 & 0.1 & 24 & 68.16 & 50 & NA & NA & NA & quench sample, residual fluid in reaction cell \\
\hline maximum $2 \sigma$ uncertainty $^{\mathrm{h}}$ & - & - & $2 \%$ & $2.6 \%$ & $5 \%$ & 0.1 & 0.1 & \\
\hline
\end{tabular}

${ }^{\mathrm{a}}$ Aqueous aluminum determined by inductively-coupled plasma optical emission spectroscopy (ICP-OES).

${ }^{\mathrm{b}}$ Aqueous sodium determined by ICP mass spectroscopy (ICP-MS).

${ }^{\mathrm{c}}$ Inorganic carbon (as $\mathrm{CO}_{2}$ ) determined by coulometric titration [Huffmann, 1977].

${ }^{\mathrm{d}}$ The $\mathrm{pH}$ measured in sample cooled to $25^{\circ} \mathrm{C}$ as determined by a Ross microelectrode.

${ }^{\mathrm{e}}$ In-situ pH calculated using Geochemist's Workbench 8.0.8 [Bethke and Yeakel, 2009], the thermodynamic dataset thermo.dat, and the b-dot ion association model. Chemical analysis and bench $\mathrm{pH}$ at $25^{\circ} \mathrm{C}$ are used as input data, then temperature is increased to 50 or $75^{\circ} \mathrm{C}$ as appropriate.

${ }^{\mathrm{f}}$ Solution used in experiment, synthesized as $0.05 \mathrm{M} \mathrm{NaHCO}_{3}$.

gA, not analyzed.

${ }^{\mathrm{h}}$ Uncertainty as reported by analytical method. Higher analytical $(2 \sigma)$ uncertainties exist for Al in starting solution (12.0\%), Al in sample collected at 449.2 hours $(10.2 \%)$, and $\mathrm{Na}$ in sample collected at 348.7 hours $(4.8 \%)$.

experimental results, and published results for dawsonite solubility, against predictions for dawsonite mineralization produced by an off-the-shelf geochemical code of a type routinely used for modeling carbon sequestration scenarios. From this analysis we demonstrate how geochemical simulations of dawsonite mineralization in a carbon repository may go astray.

\section{Reactivity of Dawsonite}

[5] A mono-mineralic hydrothermal experiment was performed to examine dawsonite reactivity at two relevant reservoir temperatures. The experiment emulates the later stages of a carbon sequestration scenario in which supercritical $\mathrm{CO}_{2}$ has already reacted with brine to precipitate dawsonite and is no longer part of the reactive system. Using established experimental methods [Kaszuba et al., 2003, 2005], 237.4 grams of 0.05 molal (M) $\mathrm{NaHCO}_{3}$ aqueous solution and 2.02 grams of synthetic dawsonite were reacted for 18.7 days (449.2 hours) at $50^{\circ} \mathrm{C}, 20 \mathrm{MPa}$ confining pressure in a rocker bomb. The temperature was then increased to $75^{\circ} \mathrm{C}$ and the experiment continued for an additional 12.3 days (295.1 hours). Synthetic dawsonite was prepared using methods described by Carey et al. [2006]. Aqueous solution was periodically sampled from the ongoing reaction during the course of the experiment whereas solids and quenched fluid were analyzed after the experiment was completed. Analytical results for fluid samples suggest that the brine achieved an approximate steady state, controlled by the alteration mineral assemblage (Table 1 and Figure 1).

[6] Greater than $95 \%$ of the original mass of dawsonite persisted in the experiment as determined by X-ray diffraction analysis of post-reaction solids. Incongruent dissolution of dawsonite yielded $\mathrm{Al}(\mathrm{OH})_{3}$ polymorphs, a mixture of gibbsite and nordstrandite (Figure S1 of the auxiliary material). ${ }^{1}$ This alteration assemblage is consistent with natural occurrences of co-existing dawsonite and $\mathrm{Al}(\mathrm{OH})_{3}$ polymorphs [Goldbery and Loughnan, 1970, 1977]:

$\mathrm{NaAlCO}_{3}(\mathrm{OH})_{2}$ (dawsonite $)+\mathrm{H}_{2} \mathrm{O}=>$
$\mathrm{Al}(\mathrm{OH})_{3}($ nordstrandite $)+\mathrm{Na}^{+}+\mathrm{HCO}_{3}^{-}$

[7] Geochemical simulations were performed to evaluate how well theoretical predictions capture the actual behavior of dawsonite in the experiments. Predictive geochemical simulations were performed using Geochemist's Workbench 8.0.8 [Bethke and Yeakel, 2009], a geochemical code used to model carbon sequestration scenarios. Simulations used the b-dot ion association model and compared two thermodynamic databases resident in the code, thermo.com.V8.R $6^{+}$ and thermo.dat. Thermo.com.V8.R6 ${ }^{+}$is tacitly accepted by geochemical modelers as a comprehensive data compilation for minerals and aqueous complexes. Thermo.dat is a less comprehensive but internally consistent database. Key reactions and equilibrium constants for these two databases are tabulated in Tables S1 and S2. (Standard $\log \mathrm{K}$ values for gibbsite, boehmite, diaspore, and corundum in thermo.com. V8. $6^{+}$are incorrect for temperatures other than $25^{\circ} \mathrm{C}$. Corrected values and an explanation are presented in Table S1.) Dawsonite, gibbsite, and the AlOOH polymorphs boehmite and diaspore were the only aluminum oxyhydroxide minerals considered in our simulations. We did not include nordstrandite or other aluminum hydroxides in the simulations because of the conflicting thermodynamic data reported for these minerals [Anovitz et al., 1991; Hemingway and Sposito, 1996; Tagirov and Schott, 2001]. Total aqueous

\footnotetext{
${ }^{1}$ Auxiliary materials are available in the HTML. doi:10.1029/ $2011 \mathrm{GL} 046845$
} 


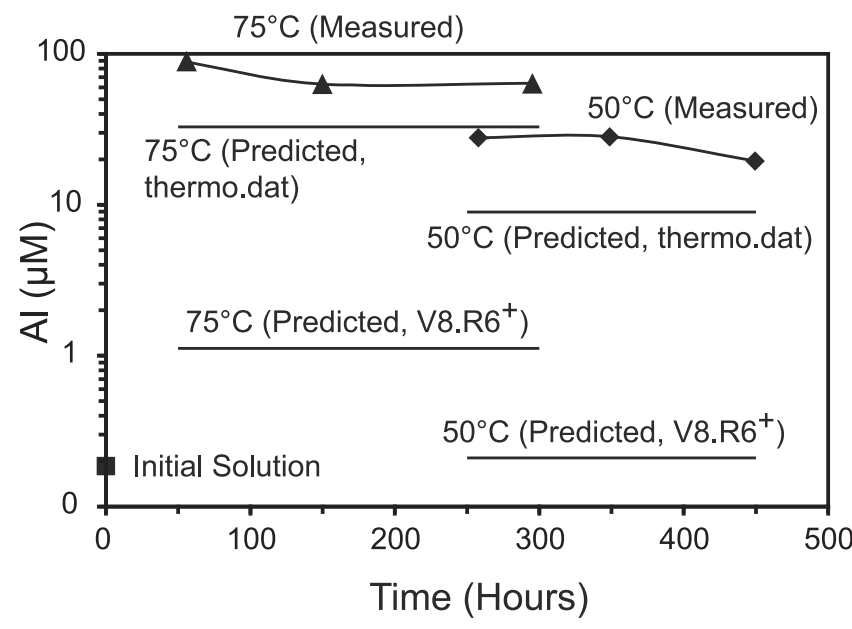

Figure 1. Analytical results for aqueous aluminum plotted as a function of time in a hydrothermal experiment conducted in two stages. Also plotted are predicted values for total dissolved aluminum in both stages of the experiment. The predictions were made using Geochemist's Workbench 8.0.8 and two thermodynamic databases resident in the code (thermo.com.V8.R6 ${ }^{+}$and thermo.dat). The amount of aluminum measured in the experiment is roughly two orders-ofmagnitude greater than values predicted using thermo.com. V8.R6 $6^{+}$, suggesting that dawsonite is less stable than portrayed by calculations using this database. In contrast, geochemical simulations using thermo.dat yield a much improved fit between experiment and simulation.

aluminum predicted by the simulations are compared with experimental data in Figure 1 (aqueous speciation, mineral saturation indices and separate calculations using experimentally generated data to calculate $i n-$ situ $\mathrm{pH}$ (Table 1) are tabulated in Tables S3 and S4).

[8] Simulations using thermo.com.V8. $6^{+}$predicted a dawsonite-diaspore assemblage with 0.21 and $1.12 \mu \mathrm{M} / \mathrm{kg}$ total dissolved aluminum at 50 and $75^{\circ} \mathrm{C}$, respectively (Figure 1). Dissolved aluminum measured in the experiment is roughly two orders-of-magnitude greater than these predicted values (Table 1 and Figure 1). Higher aqueous aluminum concentrations in the experiment suggest that dawsonite or diaspore is less stable than predicted using thermo.com.V8.R6 ${ }^{+}$(replacing diaspore by gibbsite only improves the prediction by a factor of 4-6). Discrepancies between aluminum concentrations measured in experiments and predicted by geochemical simulations have been observed elsewhere [Carey et al., 2006]. In contrast, geochemical simulations using thermo.dat predicted assemblages of dawsonite and dawsonite-gibbsite with 8.8 and $32.2 \mu \mathrm{M} / \mathrm{kg}$ dissolved aluminum at 50 and $75^{\circ} \mathrm{C}$, respectively (Figure 1). While these predictions are roughly two to three times less than experimental values, they represent a much improved match between experiment and calculation compared to simulations using thermo.com.V8.R6 ${ }^{+}$.

[9] Recently-published dawsonite solubility measurements [Bénézeth et al., 2007] provide a second, independent laboratory dataset to test predictive geochemical simulations for dawsonite mineralization. We simulated their laboratory measurements (Table S5) that were performed at the same temperatures as our experiments $\left(50\right.$ and $75^{\circ} \mathrm{C}$, Run $\# 8$ of
Bénézeth et al. [2007]). Simulations using thermo.com.V8. $\mathrm{R}^{+}$predicted dissolved aluminum approximately one order-of magnitude less than measured values whereas simulations using thermo.dat predicted dissolved aluminum within 10 to $40 \%$ of measured values. The simulation using thermo.com.V8.R6 $6^{+}$incorrectly predicted formation of diaspore. The simulation using thermo.dat predicted near saturation of gibbsite at $50^{\circ} \mathrm{C}$ and formation of gibbsite at $75^{\circ} \mathrm{C}$ whereas bayerite formed in these solubility experiments. Since the solubility of bayerite and gibbsite in sodium chloride solutions is assumed to be the same [Bénézeth et al., 2007] we interpret the results of our simulations with thermo.dat as being correct. These computational results are consistent with simulations of our experiments despite differences in the methods employed in the two studies. These differences include solution $\mathrm{pH}$ ( 9.3 to 9.8 versus 8.5 in our study) and ionic strength (1 M versus $50 \mathrm{mM})$, type of experimental apparatus (in-situ hydrogen-electrode concentration cell versus rocker bomb containing flexible gold reaction cell), $\mathrm{pH}$ measurement technique (in-situ versus ex-situ), and pressure of the experiments ( 0.1 versus $20 \mathrm{MPa}$ ).

[10] Geochemical simulations can produce erroneous results by using inaccurate thermodynamic [Oelkers et al., 2009] or kinetic data. In the case of dawsonite, thermodynamic data are well constrained [Ferrante et al., 1976] and have been independently verified [Bénézeth et al., 2007]. Values of equilibrium constants for dawsonite (Table S2) are close for both databases. Limited kinetic data are available for dawsonite. One set of dissolution experiments suggests that dawsonite stabilizes at high $\mathrm{CO}_{2}$ pressure and dissolves relatively quickly after $\mathrm{CO}_{2}$ pressure diminishes [Hellevang et al., 2005]. However, dawsonite is generally absent from naturally occurring $\mathrm{CO}_{2}$ fields in which high $\mathrm{CO}_{2}$ pressures have existed for geologically significant time [Wilkinson et al., 2009].

[11] Equilibrium constants compiled for the hydrolysis of aluminum and for aluminum oxyhydroxide minerals are the likely source of error between the two databases. Thermodynamic data for the hydrolysis of aluminum that is used in the database thermo.com.V8.R6 ${ }^{+}$[Pokrovskii and Helgeson, 1995] and in other geochemical simulations [Shock et al., 1997] contains inconsistencies that increase with temperature [Tagirov and Schott, 2001]. The relative stability of the aluminum oxyhydroxide minerals boehmite and diaspore is significantly different (1.7 to $2.0 \log$ units, Table S2) depending on the choice of thermodynamic data. Results from more recent boehmite solubility measurements [Castet et al., 1993; Bénézeth et al., 1997, 2001; Palmer et al., 2001] are the most reliable [Tagirov and Schott, 2001] but are not widely employed.

[12] The database thermo.com.V8.R6 ${ }^{+}$compiles thermodynamic data for gibbsite, boehmite, and diaspore from the work of Pokrovskii and Helgeson [1995]. Simulations using this database incorrectly predict the formation of diaspore instead of gibbsite in our experiments and in the 50 and $75^{\circ} \mathrm{C}$ experiments of Bénézeth et al. [2007]. These simulations also predict the relative stability of aluminum oxyhydroxide minerals as diaspore $>$ boehmite $>$ gibbsite (Tables S3 and S4). However, gibbsite is known to be more stable than boehmite at temperatures less than $80^{\circ} \mathrm{C}$ [Tagirov and Schott, 2001]. In contrast, simulations using thermo.dat correctly predict both formation of gibbsite in the two 
experimental studies and the relative stability of the gibbsite as greater than boehmite at these experimental conditions.

[13] Finally, large, extensive thermodynamic databases used in geochemical codes, such as thermo.com.V8.R6 ${ }^{+}$, compile thermodynamic data from several different published sources that have used a variety of different laboratory methods. The emergent aqueous model computed with these databases may not be consistent with the original aqueous data [Parkhurst and Appelo, 1999; van der Lee and Lomenech, 2004; Oelkers et al., 2009]. In the case of the database thermo.com.V8.R6 ${ }^{+}$, thermodynamic data for minerals and aqueous complexes in the system $\mathrm{Al}-\mathrm{H}_{2} \mathrm{O}$ is from one source [Pokrovskii and Helgeson, 1995] while thermodynamic data for $\mathrm{HCO}_{3}^{-}$and $\mathrm{Na}$-bearing aluminum complexes is from a second [Wagman et al., 1982]. Both of these sources are themselves compilations of criticallyassessed data.

\section{Dawsonite Mineralization in Geologic Carbon Sequestration}

[14] Computer simulations most often predict calcite, siderite, ankerite, magnesite, dolomite, and dawsonite as the mineral traps that will form in a carbon repository [Johnson et al., 2001; Xu et al., 2004; Knauss et al., 2005; Zerai et al., 2006; Xu et al., 2007]. The specific minerals and relative amounts that form depend on parameters that include brine chemistry and rock type. However, experiments that emulate a carbon sequestration scenario form siderite, magnesite, and/ or calcite, not dawsonite [Kaszuba et al., 2003, 2005; Palandri et al., 2005; Daval et al., 2009; Ketzer et al., 2009; Montes-Hernandez and Pironon, 2009]. Natural $\mathrm{CO}_{2}$ fields in which supercritical $\mathrm{CO}_{2}$, aqueous fluid, and rock co-exist contain little [Wilkinson et al., 2009] or no dawsonite [Pearce et al., 1996; Klusman, 2003]. Abundant dawsonite is associated with rather exceptional geochemical environments, most notably in oil shale of the Green River Formation [Smith and Milton, 1966] and in siliciclastic sedimentary rocks permeated by magmatic $\mathrm{CO}_{2}$ [Baker et al., 1995; Gao et al., 2009].

[15] In this study, we restricted experiments and predictive simulations to an equilibrium-based evaluation of a well-constrained, simple fluid-mineral system in order to focus on dawsonite. The extent to which model predictions emulate dawsonite solubility in these experiments depends on the interactions among aluminum oxyhydroxide minerals and aqueous complexes that compete with dawsonite to constrain aluminum solubility. The latest modeling studies that incorporate updated aluminum thermodynamic data [Gaus et al., 2008; Cantucci et al., 2009] predict dawsonite mineralization will be important in a carbon repository. Our results are directly applicable to the interpretation of dawsonite stability based on chemical analyses of natural and experimental waters. In these cases, it is clear that the size of the dawsonite stability field can be overestimated by the choice of thermodynamic data. However, while this is a piece of the dawsonite puzzle, these results do not challenge the thermodynamic stability of dawsonite at high $\mathrm{CO}_{2}$ pressure [e.g., Bénézeth et al., 2007]. Thus, in addition to the thermodynamic constraints employed in this study, additional factors must influence dawsonite reactivity. These include complexities inherent in kinetic processes and in multi-mineral multi-component brine-rock interactions characteristic of natural systems. In particular, the potential influence of multi-phase $\left(\mathrm{H}_{2} \mathrm{O}+\right.$ supercritical $\left.\mathrm{CO}_{2}\right)$ fluids on the stability of dawsonite relative to aluminosilicate minerals prevalent in natural systems may be important.

[16] Our results demonstrate the challenges in developing a realistic model for $\mathrm{CO}_{2}$ mineralization in a carbon repository over long time scales, thousands of years and longer. If performance assessment models could accurately predict mineralization, uncertainty in $\mathrm{CO}_{2}$ migration could be greatly reduced. However, our results bring into question the extent to which performance assessment models can accurately predict dawsonite mineralization when assessing a sequestration site. Confidence in these models can increase by improving the internal consistency of thermodynamic databases through relevant field and laboratory experiments that assess the thermodynamic properties of critical phases and the computer codes that simulate geologic carbon sequestration.

[17] Acknowledgments. We acknowledge Thomas Carpenter for his able assistance in the hydrothermal lab, Ren Guan for dawsonite synthesis and XRD analysis, and Dale Counce for aqueous analyses. T. Meuzelaar and $\mathrm{G}$. Thyne reviewed an earlier version of this paper. Laboratory work was funded by the LDRD program of Los Alamos National Laboratory. J. P. Kaszuba's work in data analysis and manuscript preparation was supported by the UW School of Energy Resources.

[18] The Editor thanks two anonymous reviewers for their assistance in evaluating this paper.

\section{References}

Anovitz, L. M., D. Perkins, and E. J. Essene (1991), Metastability in nearsurface rocks of minerals in the system $\mathrm{Al}_{2} \mathrm{O}_{3}-\mathrm{SiO}_{2}-\mathrm{H}_{2} \mathrm{O}$, Clays Clay Miner., 39, 225-233, doi:10.1346/CCMN.1991.0390301.

Baker, J. C., G. P. Bai, P. J. Hamilton, S. D. Golding, and J. B. Keene (1995), Continental-scale magmatic carbon dioxide seepage recorded by dawsonite in the Bowen Gunnedah-Sydney basin system, Eastern Australia, J. Sediment. Res., A65, 522-530.

Bénézeth, P., D. A. Palmer, and D. J. Wesolowski (1997), The aqueous chemistry of aluminum: A new approach to high-temperature solubility measurements, Geothermics, 26, 465-481, doi:10.1016/S0375-6505(97) 00006-0.

Bénézeth, P., D. A. Palmer, and D. J. Wesolowski (2001), Aqueous hightemperature solubility studies. II: The solubility of boehmite at $0.03 \mathrm{~m}$ ionic strength as a function of temperature and $\mathrm{pH}$ as determined by in situ measurements, Geochim. Cosmochim. Acta, 65, 2097-2111, doi:10.1016/ S0016-7037(01)00585-3.

Bénézeth, P., D. A. Palmer, L. M. Anovitz, and J. Horita (2007), Dawsonite synthesis and reevaluation of its thermodynamic properties from solubility measurements: Implications for mineral trapping of $\mathrm{CO}_{2}$, Geochim. Cosmochim. Acta, 71, 4438-4455, doi:10.1016/j.gca.2007.07.003.

Benson, S., and P. Cook (2005), Underground geological storage, in IPCC Special Report on Carbon Dioxide Capture and Storage, edited by B. Metz et al., pp. 195-276, Cambridge Univ. Press, Cambridge, U. K.

Bethke, C. M., and S. Yeakel (2009), The Geochemist's Workbench Release 8.0: Reaction Modeling Guide, 84 pp., Univ. of Ill., Champaign. Cantucci, B., G. Montegrossi, O. Vaselli, F. Tassi, F. Quattrocchi, and E. H. Perkins (2009), Geochemical modeling of $\mathrm{CO}_{2}$ storage in deep reservoirs: The Weyburn Project (Canada) case study, Chem. Geol., 265, 181-197, doi:10.1016/j.chemgeo.2008.12.029.

Carey, J. W., R.-G. Duan, and J. P. Kaszuba (2006), Crystal chemistry and reactivity of dawsonite, paper presented at GHGT-8, 8th International Conference on Greenhouse Gas Control Technologies, Elsevier Sci., Trondheim, Norway.

Castet, S., J. L. Dandurand, J. Schott, and R. Gout (1993), Boehmite solubility and aqueous aluminum speciation in hydrothermal solutions $(90$ $350^{\circ} \mathrm{C}$ ): Experimental study and modeling, Geochim. Cosmochim. Acta, 57, 4869-4884, doi:10.1016/0016-7037(93)90126-H.

Daval, D., I. Martinez, J. Corvisier, N. Findling, B. Goffé, and F. Guyot (2009), Carbonation of Ca-bearing silicates, the case of wollastonite: Experimental investigations and kinetic modeling, Chem. Geol., 265 , 63-78, doi:10.1016/j.chemgeo.2009.01.022. 
Ferrante, M. J., J. M. Stuve, and D. W. Richardson (1976), Thermodynamic data for synthetic dawsonite, Rep. of Invest., 8129, 13 pp., U.S. Bur. of Mines, Washington, D. C.

Gao, Y. Q., L. Liu, and W. X. Hu (2009), Petrology and isotopic geochemistry of dawsonite-bearing sandstones in Hailaer basin, northeastern China, Appl. Geochem., 24, 1724-1738, doi:10.1016/j.apgeochem. 2009.05.002.

Gaus, I., P. Audigane, L. Andre, J. Lions, N. Jacquemet, P. Dutst, I. Czernichowski-Lauriol, and M. Azaroual (2008), Geochemical and solute transport modelling for $\mathrm{CO}_{2}$ storage, what to expect from it?, Int. J. Greenhouse Gas Control, 2, 605-625, doi:10.1016/j.ijggc.2008.02.011. Goldbery, R., and F. C. Loughnan (1970), Dawsonite and nordstrandite in Permian Berry Formation of Sydney Basin, New South Wales, Am. Mineral., 55, 477-490.

Goldbery, R., and F. C. Loughnan (1977), Dawsonite, alumohydrocalcite, nordstrandite and gorceixite in Permian marine strata of Sydney Basin, Australia, Sedimentology, 24, 565-579, doi:10.1111/j.1365-3091.1977. tb00139.x.

Hangx, S. J. T., and C. J. Spiers (2009), Reaction of plagioclase feldspars with $\mathrm{CO}_{2}$ under hydrothermal conditions, Chem. Geol., 265, 88-98, doi:10.1016/j.chemgeo.2008.12.005.

Hellevang, H., P. Aagaard, E. H. Oelkers, and B. Kvamme (2005), Can dawsonite permanently trap $\mathrm{CO}_{2}$ ?, Environ. Sci. Technol., 39, 8281-8287, doi:10.1021/es0504791.

Hellevang, H., J. Declercq, B. Kvamme, and P. Aagaard (2010), The dissolution rates of dawsonite at $\mathrm{pH} 0.9$ to 5 and temperatures of 22,60 and $77^{\circ} \mathrm{C}$, Appl. Geochem., 25, 1575-1586, doi:10.1016/j.apgeochem. 2010.08.007.

Hemingway, B. S., and G. Sposito (1996), Inorganic aluminium-bearing solid phases, in The Environmental Chemistry of Aluminium, edited by G. Sposito, pp. 81-116, CRC Press, Boca Raton, Fla.

Huffmann, E. (1977), Performance of a new automatic carbon dioxide coulometer, Microchem. J., 22, 567-573.

Johnson, J. W., J. J. Nitao, C. I. Steefel, and K. G. Knauss (2001), Reactive transport modeling of geologic $\mathrm{CO}_{2}$ sequestration in saline aquifers: The influence of intra-aquifer shales and the relative effectiveness of structural solubility and mineral trapping during prograde and retrograde sequestration, paper presented at First National Conference on Carbon Sequation, Natl. Energy Technol. Lab., U.S. Dep. of Energy, Washington, D. C., 14-17 May.

Kaszuba, J. P., D. R. Janecky, and M. G. Snow (2003), Carbon dioxide reaction processes in a model brine aquifer at $200^{\circ} \mathrm{C}$ and 200 bars: Implications for geologic sequestration of carbon, Appl. Geochem., 18, 1065-1080, doi:10.1016/S0883-2927(02)00239-1.

Kaszuba, J. P., D. R. Janecky, and M. G. Snow (2005), Experimental evaluation of mixed fluid reactions between supercritical carbon dioxide and $\mathrm{NaCl}$ brine: Relevance to the integrity of a geologic carbon repository, Chem. Geol., 217, 277-293, doi:10.1016/j.chemgeo.2004.12.014.

Ketzer, J. M., R. Iglesias, S. Einloft, J. Dullius, R. Ligabue, and V. de Lima (2009), Water-rock- $\mathrm{CO}_{2}$ interactions in saline aquifers aimed for carbon dioxide storage: Experimental and numerical modeling studies of the Rio Bonito Formation (Permian), southern Brazil, Appl. Geochem., 24, 760-767, doi:10.1016/j.apgeochem.2009.01.001.

Klusman, R. W. (2003), A geochemical perspective and assessment of leakage potential for a mature carbon dioxide-enhanced oil recovery project and as a prototype for carbon dioxide sequestration; Rangely field, Colorado, AAPG Bull., 87, 1485-1507, doi:10.1306/04220302032.

Knauss, K. G., J. W. Johnson, and C. I. Steefel (2005), Evaluation of the impact of $\mathrm{CO}_{2}$, co-contaminant gas, aqueous fluid and reservoir rock interactions on the geologic sequestration of $\mathrm{CO}_{2}$, Chem. Geol., 217, 339-350, doi:10.1016/j.chemgeo.2004.12.017.

Montes-Hernandez, G., and J. Pironon (2009), Hematite and iron carbonate precipitation-coexistence at the iron-montmorillonite-salt solution$\mathrm{CO}_{2}$ interfaces under high gas pressure at $150^{\circ} \mathrm{C}, \mathrm{Appl}$. Clay Sci., 45 , 194-200, doi:10.1016/j.clay.2009.06.004.

Newell, D. L., J. P. Kaszuba, H. S. Viswanathan, R. J. Pawar, and T. Carpenter (2008), Significance of carbonate buffers in natural waters reacting with supercritical $\mathrm{CO}_{2}$ : Implications for monitoring, measuring and verification (MMV) of geologic carbon sequestration, Geophys. Res. Lett., 35, L23403, doi:10.1029/2008GL035615.
Oelkers, E. H., P. Bénézeth, and G. S. Pokrovski (2009), Thermodynamic databases for water-rock interaction, in Thermodynamics and Kinetics of Water-Rock Interaction, edited by E. H. Oelkers and J. Schott, pp. 1-46, Mineral. Soc Am., Chantilly, Va.

Palandri, J. L., R. J. Rosenbauer, and Y. K. Kharaka (2005), Ferric iron in sediments as a novel $\mathrm{CO}_{2}$ mineral trap: $\mathrm{CO}_{2}-\mathrm{SO}_{2}$ reaction with hematite, Appl. Geochem., 20, 2038-2048, doi:10.1016/j.apgeochem.2005.06.005.

Palmer, D. A., P. Bénézeth, and D. J. Wesolowski (2001), Aqueous hightemperature solubility studies. I. The solubility of boehmite as functions of ionic strength (to 5 molal, $\mathrm{NaCl}$ ), temperature $\left(100-290^{\circ} \mathrm{C}\right)$, and $\mathrm{pH}$ as determined by in situ measurements, Geochim. Cosmochim. Acta, 65, 2081-2095, doi:10.1016/S0016-7037(01)00584-1.

Parkhurst, D. L., and C. A. J. Appelo (1999), User's guide to PHREEQC (v. 2): A computer program for speciation, batch-reaction, one-dimensional transport, and inverse geochemical calculations, U.S. Geol. Surv. Water Resour. Invest. Rep., WRI 99-4259, 312 pp.

Pearce, J. M., S. Holloway, H. Wacker, M. K. Nelis, C. Rochelle, and K. Bateman (1996), Natural occurrences as analogues for the geological disposal of carbon dioxide, Energy Convers. Manage., 37, 1123-1128, doi:10.1016/0196-8904(95)00309-6.

Pokrovskii, V. A., and H. C. Helgeson (1995), Thermodynamic properties of aqueous species and the solubilities of minerals at high pressures and temperatures: The system $\mathrm{Al}_{2} \mathrm{O}_{3}-\mathrm{H}_{2} \mathrm{O}-\mathrm{NaCl}, \mathrm{Am}$. J. Sci., 295, 1255-1342, doi:10.2475/ajs.295.10.1255.

Shock, E. L., D. C. Sassani, M. Willis, and D. A. Sverjensky (1997), Inorganic species in geologic fluids: Correlations among standard molal thermodynamic properties of aqueous ions and hydroxide complexes, Geochim. Cosmochim. Acta, 61, 907-950, doi:10.1016/S0016-7037 (96)00339-0.

Smith, J. W., and C. Milton (1966), Dawsonite in the Green River Formation of Colorado, Econ. Geol., 61, 1029-1042, doi:10.2113/gsecongeo. 61.6.1029.

Tagirov, B., and J. Schott (2001), Aluminum speciation in crustal fluids revisited, Geochim. Cosmochim. Acta, 65, 3965-3992, doi:10.1016/ S0016-7037(01)00705-0.

van der Lee, J., and C. Lomenech (2004), Towards a common thermodynamic database for speciation models, Radiochim. Acta, 92, 811-818, doi:10.1524/ract.92.9.811.54998.

Viswanathan, H. S., R. J. Pawar, P. H. Stauffer, J. P. Kaszuba, J. W. Carey, S. C. Olsen, G. N. Keating, D. Kavetski, and G. D. Guthrie (2008), Development of a hybrid process and system model for the assessment of wellbore leakage at a geologic $\mathrm{CO}_{2}$ sequestration site, Environ. Sci. Technol., 42, 7280-7286, doi:10.1021/es800417x.

Wagman, D. D., W. H. Evans, V. B. Parker, R. H. Schumm, I. Halow, S. M. Bailey, K. L. Churney, and R. L. Nuttall (1982), The NBS tables of chemical thermodynamic properties - Selected values for inorganic and C1 and C2 organic substances in SI units, report, 392 pp., Am. Chem. Soc., Washington, D. C.

Wilkinson, M., R. S. Haszeldine, A. E. Fallick, N. Odling, S. J. Stoker, and R. W. Gatliff (2009), $\mathrm{CO}_{2}$-mineral reaction in a natural analogue for $\mathrm{CO}_{2}$ storage: Implications for modeling, J. Sediment. Res., 79, 486-494, doi:10.2110/jsr.2009.052

$\mathrm{Xu}, \mathrm{T}$. F., J. A. Apps, and K. Pruess (2004), Numerical simulation of $\mathrm{CO}_{2}$ disposal by mineral trapping in deep aquifers, Appl. Geochem., 19, 917-936, doi:10.1016/j.apgeochem.2003.11.003.

Xu, T. F., J. A. Apps, K. Pruess, and H. Yamamoto (2007), Numerical modeling of injection and mineral trapping of $\mathrm{CO}_{2}$ with $\mathrm{H}_{2} \mathrm{~S}$ and $\mathrm{SO}_{2}$ in a sandstone formation, Chem. Geol., 242, 319-346, doi:10.1016/j. chemgeo.2007.03.022.

Zerai, B., B. Z. Saylor, and G. Matisoff (2006), Computer simulation of $\mathrm{CO}_{2}$ trapped through mineral precipitation in the Rose Run Sandstone, Ohio, Appl. Geochem., 21, 223-240, doi:10.1016/j.apgeochem. 2005.11.002.

J. W. Carey and H. S. Viswanathan, Earth and Environmental Sciences Division, Los Alamos National Laboratory, PO Box 1663, Los Alamos, NM 87545, USA.

J. P. Kaszuba, Department of Geology and Geophysics and School of Energy Resources, University of Wyoming, Laramie, WY 82071, USA. 